\title{
URGENSI ETIKA BISNIS DALAM WUJUDKAN TANGGUNG JAWAB SOSIAL DAN LINGKUNGAN PERUSAHAAN SESUAI UNDANG-UNDANG NO. 40 TAHUN 2007 TENTANG PERSEROAN TERBATAS
}

\section{URGENCY OF BUSINESS ETHICS IN REALIZING CORPORATE SOCIAL RESPONSIBILITY IN ACCORDANCE WITH LAW NO. 40 OF 2007 CONCERNING LIMITED LIABILITY COMPANIES}

\author{
Muhamad Hudory dan \\ Muhammad Taufiq
}

\author{
Program Studi Hukum Sekolah Pascasarjana \\ Universitas Djuanda Bogor \\ Jl. Tol Ciawi No. 1, Kotak Pos 35, Bogor 16720. \\ Korespondensi : Muhamad Hudory, Telp. - \\ e-mail : muhamad.hudory@unida.ac.id
}

Jurnal Abstract : The implementation of social and environmental responsibility or Living Law, commonly called Corporate Social Responsibility (CSR) is a function of the company in Vol. 11, No. realizing social responsibility towards the environment and related parties in order to

1, 2019 hlm. 50-60 create a healthy and prosperous society. The method in this study is the Normative Juridical Approach, namely law is conceptualized as norms, rules, principles or dogmas. Juridical Sociological Approach (Empirical), namely law as a symptom of society as a social institution or patterned behavior, this approach is known as empirical legal research or sociological legal research. Social and environmental responsibility even though it is not mandatory normatively in legislation but from the moral aspect of CSR this is a manifestation of social ethics and concern for a company towards the environment and society.

Keywords : Business Ethics, CSR, limited liability company.

\begin{abstract}
Abstrak : Pelaksanaan tanggung jawab sosial dan lingkungan atau biasa disebut Corporate Social Responsibility (CSR) merupakan suatu fungsi perusahaan dalam mewujudkan tanggung jawab sosial terhadap lingkungan serta para pihak yang terkait guna menciptakan masyarakat yang sehat dan sejahtera. Adapun metode dalam penelitian ini adalah Pendekatan Yuridis Normatif yaitu hukum dikonsepsikan sebagai norma, kaidah, asas atau dogma-dogma. Pendekatan Yuridis Sosiologis (Empiris), yaitu hukum sebagai gejala masyarakat sebagai institusi sosial atau perilaku yang mempola, pendekatan ini dikenal dengan penelitian hukum yang empirik atau penelitian hukum sosiologis. Tanggung jawab sosial dan lingkungan meski tidak wajib secara normative perundang-undangan namun dari aspek moral CSR ini sebagai bentuk perwujudan etika sosial dan kepedulian sebuah perusahaan terhadap lingkungan dan masyarakat.
\end{abstract}

Kata Kunci : Etika Bisnis, CSR, Perseroan Terbatas.

\section{PENDAHULUAN}

Tanggung Jawab Sosial dan Lingkungan (selanjutnya disebut TJSL) adalah padanan kata yang digunakan di dalam UndangUndang No. 40 Tahun 2007 tentang Perseroan Terbatas untuk penggunaan istilah Corporate Social Responsibility (selanjutnya disebut CSR). CSR atau TJSL sebagai suatu konsep, berkembang pesat sejak 1980-an hingga 1990-an sebagai reaksi dan suara keprihatinan dari organisasi-organisasi masyarakat sipil dan jaringan tingkat global untuk meningkatkan perilaku etis, fairness dan responsibilitas perusahaan yang tidak hanya terbatas pada perusahaan, tetapi juga pada para stakeholder dan komunitas 
atau masyarakat sekitar wilayah kerja dan operasinya. ${ }^{1}$

Pada tahun 1992, Konferensi Tingkat Tinggi (selanjutnya disebut KTT) Bumi di Rio de Janeiro Brazilia menegaskan konsep pembangunan yang berkelanjutan (sustainibility development) sebagai hal yang wajib diperhatikan, tidak hanya oleh negara tetapi terlebih oleh kalangan perusahaan yang kekuatan kapitalnya semakin menggurita. Salah satu hasil KTT tersebut antara lain : menyepakati perubahan paradigma pembangunan, dari pertumbuhan ekonomi (economic growth) menjadi pembangunan yang berkelanjutan (sustainable development). ${ }^{2}$

Pada tahun 2002, para Pemimpin Dunia di Yohannesburg telah mengajukan dan melahirkan konsep social responsibility untuk menggenapi dua paradigma pembangunan sebelumnya yaitu economic growth dan environment sustainability. ${ }^{3}$ Ketiganya menjadi dasar bagi perusahaan untuk menerapkan CSR/TJSL di dalam menjalankan perusahaannya. Pada pertemuan United Nation Global Compact di Jenewa, Swiss tahun 2007 perusahaan diminta untuk menunjukkan penerapan dan pelaksanaan tanggung jawab dan perilaku bisnis yang sehat, dikenal dengan CSR. ${ }^{4}$

1 Gunawan Widjaja, Seri Pemahaman Perseroan Terbatas 150 Tanya Jawab tentang Perseroan Terbatas, Cetakan Pertama, (Jakarta : Forum Sahabat, Agustus 2008), hal. 96.

${ }^{2}$ Website Kementerian Lingkungan Hidup, "Berikan Kesempatan Pada Bumi (Give Earth $A$ Chance)", http://www.menm. go. id/home/index.php?Itemid=237\&id=437\%3ABER IKAN-

KESEMPATAN-PADA-BUMI-(Give-Earth-a-

Chance)\&lang=id\&option=com_content $\&$ view $=$ arti cle., diakses pada 03 Juni 2017.

${ }^{3}$ Website Departemen Kehutanan, "Milestone : Kehutanan Dalam Forum Global", http://www.dephut.go.id/Halaman/Bukubuku/2004/KLN/Milestone.htm., diakses pada 03 Juni 2017.

${ }^{4}$ Andreas Rasche dan Georg Kell (Editor), United Nations Global Compact: Achievements, Trends and Challenges, (New York : Cambridge University Press, 2010), hal. 246-247.
Gagasan utama yang tersebut di dalam CSR/TJSL, perusahaan tidak lagi dihadapkan pada tanggung jawab yang berpijak hanya pada single bottle lines yaitu

"Nilai perusahaan (corporate value) yang direfleksikan dalam kondisi keuangannya (financial) saja, tetapi tanggung jawab perusahaan harus berpijak pada triple bottom lines, yaitu berupa : finansial, sosial dan lingkungan. Kondisi keuangan saja tidak cukup menjamin nilai perusahaan tumbuh dan berkembang secara berkelanjutan (sustainable). Keberlanjutan perusahaan akan terjamin apabila perusahaan juga turut memperhatikan dimensi sosial dan lingkungan hidup. 5

Sebagai contoh : ada laporan keberlanjutan sebuah perusahaan migas yang memilih acara sunatan massal sebagai program sosial unggulan. Padahal, perusahaan tersebut banyak mengubah bentang alam hutan. Secara sosial sekedar sebuah ilustrasi perusahaan tersebut sebaiknya menunjukkan diri sebagai perusahaan yang mampu mengkompensasi hilangnya hutan kepada masyarakat adat setempat misalnya dengan programprogram pemandirian ekonomi, serta mampu mengambil banyak pelajaran dari kearifan lokal".6

Ada tiga hal pokok yang menjadi faktor utama perkembangan CSR/TJSL pada periode berikutnya, yaitu :

Sifat voluntairly atau sukarela menjadi dasar penting di dalam perkembangan pelaksanaan prinsip CSR/TJSL;

Dirumuskannya suatu panduan dan standarisasi untuk menerapkan CSR/TJSL. Pada konteks ini, International Organization for Standarization (ISO) di bulan September, tahun 2004 membentuk Working Group Responsibility ISO; dan

${ }^{5}$ CSR Indonesia, "Editorial : Dokumen Laporan Keberlanjutan Bukan Sekedar Souvenir", Harian Mingguan CSR Indonesia, Volume 1, Minggu ke-37 2007, hal. 2.

${ }^{6}$ Ibid. 
Standar pedoman yang bersifat sukarela mengenai tanggung jawab sosial tersebut mencakup semua sektor, badan yang bersifat publik ataupun privat, baik di negara berkembang maupun negara maju". ${ }^{7}$

ISO 26000 menerjemahkan tanggung jawab sosial sebagai tanggung jawab organisasi akan dampak dari keputusan dan aktivitasnya terhadap masyarakat dan lingkungan hidup, melalui perilaku yang transparan dan etis, untuk konsisten dengan pembangunan berkelanjutan dan kesejahteraan masyarakat. Adapun prinsipprinsip dasar tanggung jawab sosial yang menjadi dasar bagi pelaksanaan yang menjiwai atau menjadi informasi dalam membuat keputusan dan kegiatan tanggung jawab sosial menurut ISO 26000, meliputi antara lain : menghormati stakeholders dan kepentingannya, melaksanakan transparansi dan akuntabilitas, perilaku, beretika, melakukan tindakan pencegahan, dan menghormati hak asasi manusia. ${ }^{8}$

Ada berbagai prinsip lain yang mendukung dan mengatur pelaksanaan CSR/TJSL, selain ISO 26000, yaitu antara lain :

"Equator Principles, banyak diadopsi oleh lembaga keuangan internasional; ${ }^{9}$

${ }^{7}$ Sukarmi, "Tanggung Jawab Sosial Perusahaan \{Corporate Social Responsibility) dan Iklim Penanaman Modal", Dirjend Peraturan PerundangUndangan Kementerian Hukum dan Hak Azasi Manusia Republik Indonesia,

http://www.djpp.depkumham.go.id/hukumbisnis/84-tanggung-jawab-sosial-perusahaancorporate-social-responsibility-dan-iklimpenanaman-modal.html., diakses pada 03 Juni 2017

${ }^{8}$ Bart Slob, et.al., "Briefing Paper, The ISO Working Group on Social Responsibility : Developing the future ISO SR 26000 Standard", AAmsterdam : Centre for Research on Multinational Corporations Kaizersgracht, Maret 2007), hal. 2.

${ }^{9}$ Prinsip-Prinsip Equator (EP) adalah kerangka kerja manajemen resiko kredit untuk menentukan, menilai dan mengelola resiko lingkungan dan sosial dalam transaksi pembiayaan proyek.Proyek keuangan sering digunakan untuk membiayai pengembangan dan pembangunan infrastruktur utama dan proyek EP. Industri yang
Accountability's (AA1000) Standard, didasarkan pada prinsip "triple bottom line" (profit, people, planet) yang digagas oleh John Elkington;

Global Reporting Initiative's (GRI), panduan pelaporan perusahaan untuk mendukung pembangunan berkesinambungan yang digagas oleh PBB lewat Coalition for Environmental Responsible Economies (CERES) dan UNEP tahun 1997;

Social Accountability International 's SA8000 Standard;

ISO 1400 Environmental Management Standard".10

Jika satu perusahaan sudah mengurangi daya dukung dan daya tampung suatu daerah atau wilayah tempatnya berdiri maka perusahaan tersebut wajib untuk mengembalikan keadaan lingkungan sekitar perusahaan tersebut seperti sedia kala sebelum perusahaan itu memasuki wilayah operasionalnya.

Tekanan masyarakat agar perusahaan lebih peduli kepada lingkungan merupakan kesempatan untuk memperkuat antara perusahaan dengan konsumen, bahkan dapat dijadikan keunggulan. Konsumen yang semakin sadar terhadap isu lingkungan akan mencari produk yang bersahabat dengan lingkungan. Sebagai dampak ikutannya perusahaan akan

diadopsi secara sukarela oleh lembaga keuangan dan ditetapkan dimana biaya total proyek modal melebihi US\$. 10 juta. Para EP terutama ditujukan untuk memberikan standar minimum untuk due diligence yang bertanggung jawab untuk mengambil keputusan resiko. Sumber : Equator Principles, "About The Equator Principles'" http://www.equator-

principles.com/index.php/about-the-equator-

principles., diakses pada 03 Juni 2011. Lihat juga : William B Werther Jr., dan David Chandler, Strategic Corporate Social Responsibility, Edisi Kedua, (California : SAGE Publications Inc., 2010), hal. 231232.

${ }^{10}$ Ataur Rahman Belal, Corporate Social Responsibility Reporting in Developing Country : The Case of Bangladesh, (Burlington : Ashgate Publishing Company, 2008), hal. 2-3. 
mencari pemasok yang bisa memecahkan persoalan-persoalan lingkungan. Hubungan antar perusahaan juga akan berubah, karena sama-sama ditekan untuk menjadi ramah lingkungan. Maka banyak perusahaan, terutama perusahaan besar, mulai cerewet terhadap pamasokpemasoknya. Bagi perusahaan-perusahaan bereputasi besar, menerapkan CSR adalah aset terpenting perusahaan. Walaupun hanya belakangan ini istilah CSR dikenal, sesungguhnya aktivitas community outreach atau penjangkauan masyarakat sudah dilakukan oleh perusahaan sejak dahulu kala. ${ }^{11}$

Bentuk community outreach yang paling primitif adalah corporate philanthropy, merupakan sebuah usaha yang dilakukan oleh perusahaan, atau seseorang untuk memberikan dana kepada individu atau kelompok masyarakat, misalnya dalam bentuk beasiswa. Seiring waktu berlalu, Corporate Philanthropy (CP) kemudian berkembang menjadi Corporate Social Responsibility (CSR). CSR berbeda dengan philanthropy dari dimensi keterlibatan si pemberi dana dalam aktivitas yang dilakukannya. Kegiatan CSR seringkali dilakukan sendiri oleh perusahaan, atau dengan melibatkan pihak ketiga (misalnya Yayasan atau Lembaga Swadaya Masyarakat) sebagai penyelenggara kegiatan tersebut. Melalui CSR, perusahaan jauh lebih terlibat dan terhubung dengan pihak pertama (beneficiaries) dalam aktivitas sosial dibandingkan dengan CP.33 Corporate Philanthropy inilah yang merupakan asal muasal dari Corporate Social Responsibility . Perbedaannya adalah bahwa CP tidak diberitahukan kepada media massa ketika sebuah perusahaan menyumbangkan dananya kepada masyarakat, sedangkan CSR selalu diberitakan di media. Namun, persamaannya tetap Corporate Philanthropy maupun Corporate Social Responsibility adalah bukan suatu kewajiban hukum.

11 Ibid, hal 7-8
Pelaksanaan CSR selama ini hanya didasarkan kepada kesadaran dan komitmen perusahaan. Padahal komitmen dan kesadaran setiap perusahaan tidak sama dan sangat tergantung sekali kepada kebijakan perusahaan masing-masing. Menggantungkan pelaksanaan CSR kepada kesadaran dan komitmen perusahaan mempunyai beberapa kelemahan. Kelemahan paling mendasar adalah tidak adanya sanksi yang tegas bagi perusahaan yang tidak melaksanakan CSR. Kondisi ini tidak akan mendorong pelaksanaan CSR di Indonesia. Selama ini juga, bagi perusahaan yang melaksanakan CSR tidak memilki arah yang jelas. Padahal ada banyak sekali manfaat yang diperoleh apabila CSR dilaksanakan dengan aturan dan arahan yang jelas. ${ }^{12}$

Contohnya apabila CSR diarahkan pada sektor tertentu seperti pendidikan, maka betapa banyaknya manfaat yang diperoleh. Masyarakat yang kurang mampu akan ditolong dengan CSR ini dalam hal peningkatan kualitas pendidikan mereka. Pemerintah juga akan sangat ditolong dalam melaksanakan tanggung jawabnya dalam pencerdasan kehidupan bangsa. Tentunya, itu semua dapat dilaksanakan bilamana ada regulasi yang jelas tentang CSR. Kelemahan lain dengan tidak adanya regulasi yang jelas tentang CSR adalah semakin dirugikannya masyarakat dan juga negara. Berbagai peristiwa yang terjadi di Indonesia seperti banjir lumpur, banjir karena pembalakan hutan dan pencemaran lingkungan di berbagai tempat menunjukan bahwa pelaksanaan CSR merupakan suatu kemutlakan. Apabila kondisi seperti sekarang terus berlanjut, maka yang menanggung kerugian terbesar adalah masyarakat dan negara.

Regulasi CSR juga sebenarnya bukan hal baru dalam dunia perusahaan. Di berbagai negara maju, setiap perusahaan

\footnotetext{
${ }^{12}$ Joe M. Ricks Jr., "The Effects of Strategic Corporate Philanthropy on Consumer Perceptions : An Experimental Assessment", (New Orleans : Disertasi, University of New Orleans, May 2002), hal. 1.
} 
tidak diwajibkan untuk melaksanakan CSR dan melaporkannya secara periodik. Hal ini dilakukan untuk memantau dan mengontrol pelaksanaan CSR setiap perusahaan. Regulasi yang ada juga memberikan sanksi yang tegas bagi pelanggaran terhadap pelaksanaan CSR. Sanksi yang diberikan mulai dari yang ringan seperti peringatan tertulis hingga dikeluarkan dari lantai bursa bagi perusahaan go public.

Penerapan CSR di Indonesia semakin meningkat baik dalam kuantitas maupun kualitas. Selain keragaman kegiatan dan pengelolaannya semakin bervariasi, dilihat dari kontribusi finansial, jumlahnya semakin besar. Penelitian PIRAC pada tahun 2001 menunjukkan bahwa dana CSR di Indonesia mencapai lebih dari Rp. 115.000.000.000,- (seratus lima belas miliar rupiah) atau sekitar US\$. 11.500.000,- (sebelas juta lima ratus ribu dollar amerika) dari 180 (seratus delapan puluh) perusahaan yang dibelanjakan untuk 279 (dua ratus tujuh puluh sembilan) kegiatan sosial yang terekam oleh media massa. Meskipun dana ini masih sangat kecil jika dibandingkan dengan dana CSR di Amerika Serikat, dilihat dari angka kumulatif tersebut, perkembangan CSR di Indonesia cukup menggembirakan. ${ }^{13}$

Berdasarkan uraian di atas dapat dilihat bahwa CSR/TJSL penting untuk diteliti karena beberapa persoalan antara lain seperti : pengaturan CSR/TJSL yang belum jelas karena kondisi keuangan setiap perusahaan berbeda-beda; hukum dapat melaksanakan CSR/TJSL yang diwajibkan karena pengaturan CSR/TJSL dianggap sudah tercakup pada berbagai peraturan perundang-undangan lain dalam bentuk tanggung jawab sosial perusahaan. Maka dengan demikian penelitian berjudul "Analisis Yuridis Tanggung Jawab Sosial

${ }^{13}$ Saidi dalam Bing Bedjo Tanudjaja, "Perkembangan Corporate Social Responsibility di Indonesia"", http ://puslit2 .petra. ac.id/ej ournal/index.php/dkv/article/viewFile/17049/170 13., diakses pada 27 Juni 2017, hal. 95. dan Lingkungan Perusahaan (Corporate Social Responsibility - CSR) Berdasarkan Pasal 74 Undang-Undang No. 40 Tahun 2007 tentang Perseroan Terbatas, (Studi Terhadap Putusan Mahkamah Konstitusi Nomor 53/PUU-VI/2008)" sangatlah penting untuk dibahas dan dicermati secara lebih mendalam walaupun sudah banyak penelitian-penelitian sebelumnya yang membahas masalah CSR/TJSL perusahaan di Indonesia.

Berdasarkan latar belakang tersebut di atas maka dapat diidentifikasikan permasalahan sebagai berikut :

1. Bagaimana konsep Corporate Social Responsibility (CSR) berdasarkan Undang-Undang No. 40 Tahun 2007 tentang Perseroan Terbatas?

2. Bagaimana pelaksanaan Tanggung Jawab Sosial dan Lingkungan (Corporate Social Responsibility-CSR) menurut Undang-Undang No. 40 Tahun 2007 tentang Perseroan Terbatas?

\section{METODE PENELITIAN}

Penulis dalam penelitian ini menggunakan Metode Pendekatan Yuridis Normatif dan Yuridis Sosiologis (Empiris).

Pendekatan Yuridis Normatif yaitu hukum dikonsepsikan sebagai norma, kaidah, asa atau dogma-dogma. Pendekatan yuridis normatif dikenal pula dengan istilah pendekatan/penelitian doctrinal atau penelitian normatif. penelitian hukum normatif yaitu penelitian hukum yang dilakukan dengan cara meneliti bahan pustaka atau penelaahan terhadap literature namun sepanjang diperlukan, dapat dilakukan interview, untuk melengkapi studi kepustakaan termasuk kedalam kajian/ pendekatan yuridis normative di antaranya adalah sejarah hukum, dan perbandingan hukum, juga filsafat hukum. Dalam penelitian ini bahan pustaka merupakan data dasar penelitian yang digolongkan sebagai data sekunder. ${ }^{14}$

14 Ibid, hlm 52 


\section{PEMBAHASAN}

\section{A. CORPORATE SOCIAL RESPONSIBILITY (CSR) PADA UMUMNYA}

Pasal 1 angka 3 Undang-Undang No. 40 Tahun 2007 tentang Perseroan Terbatas tampaknya menggunakan istilah Tanggung Jawab Sosial dan Lingkungan (TJSL) sebagai terjemahan dari istilah Corporate Social Responsibility (CSR) untuk konteks perusahaan dalam masyarakat Indonesia, dan mengartikannya sebagai "Komitmen perseroan untuk berperan serta dalam pembangunan ekonomi berkelanjutan guna meningkatkan kualitas kehidupan dan lingkungan yang bermanfaat, baik bagi perseroan sendiri, komunitas setempat, maupun masyarakat pada umumnya". Pada tingkat paling dasar namun sekaligus sangat luas, CSR/TJSL dapat dipahami sebagai sebuah relasi atau interkoneksi antara perusahaan dengan para pemangku kepentingan perusahaan tersebut, termasuk misalnya dengan pelanggan, pemasok, kreditur, karyawan, hingga masyarakat khususnya mereka yang berdomisili di wilayah perusahaan tersebut menjalankan aktivitas operasionalnya.

Perusahaan bertanggung jawab untuk menjamin bahwa kegiatan operasionalnya mampu menghasilkan barang dan/atau jasa secara ekonomis, efisien, dan bermutu untuk kepuasan pelanggan disamping untuk memperoleh keuntungan. Perusahaan juga berkewajiban untuk mematuhi hukum dan seluruh peraturan perundang- undangan nasional dan daerah yang berlaku di dalam wilayah negara seperti misalnya mematuhi aturan hukum ketenagakerjaan, persaingan usaha yang sehat, perlindungan terhadap konsumen, perpajakan, pelaporan aktivitas perusahaan, dan seterusnya termasuk juga untuk mematuhi hak-hak asasi manusia dan asas pengelolaan lingkungan hidup yang baik dan berkelanjutan. ${ }^{15}$

15 AF. Elly Erawaty, "Persoalan Hukum Seputar Tanggung Jawab Sosial Perseroan Dalam Perundang-Undangan Ekonomi Indonesia", (Jakarta
CSR merupakan konsep yang terus berkembang. CSR belum memiliki sebuah definisi standard maupun seperangkat kriteria spesifik yang diakui secara penuh oleh pihak-pihak yang terlibat di dalamnya. Secara konseptual, CSR juga bersinggungan dan bahkan sering dipertukarkan dengan frasa lain, seperti corporate responsibility, corporate sustainability, corporate accountability, corporate citizenship, dan corporate stewardship. CSR diterapkan kepada perusahaan-perusahaan yang beroperasi dalam konteks ekonomi global, nasional maupun lokal. Komitmen dan aktivitas CSR pada intinya merujuk pada aspek-aspek perilaku perusahaan (firm's behaviour), termasuk kebijakan dan program perusahaan yang menyangkut dua elemen kunci16 :

1. "Good Corporate Governance : etika bisnis, manajemen sumber daya manusia, jaminan sosial bagi pegawai, serta kesehatan dan keselamatan kerja;

2. Good Corporate Responsibility : pelestarian lingkungan, pengembangan masyarakat (community development), perlindungan hak azasi manusia, perlindungan konsumen, relasi dengan pemasok, dan penghormatan terhadap hak-hak pemangku kepentingan lainnya".

\section{B. PENERAPAN TANGGUNG JAWAB SOSIAL DAN LINGKUNGAN (CORPORATE SOCIAL RESPONSIBILITY) BERSIFAT VOLUNTARY (SUKARELA)}

CSR/TJSL adalah suatu konsep bahwa organisasi, khususnya (namun bukan

\footnotetext{
: Kementerian Hukum \& HAM RI, Direktorat Jenderal Peraturan Perundangan-Undangan, Media Publikasi Peraturan Perundang-Undangan dan Informasi Hukum, 28 Oktober 2010), hlm . 1.

16 Edi Suharto, "Corporate Social Responsibility : Konsep dan Perkembangan Pemikiran", makalah pembicara disampaikan pada Workshop Tanggung Jawab Sosial Perusahaan di Yogyakarta, Kerjasama Pusat Studi Hak Asasi Manusia Universitas Islam Indonesia \& Norwegian Centre for Human Rights, diselenggarakan pada 06-08 Mei 2008, hlm. 1.
} 
hanya) perusahaan adalah memiliki suatu tanggung jawab terhadap konsumen, karyawan, pemegang saham, komunitas dan lingkungan dalam segala aspek operasional perusahaan. CSR berhubungan erat dengan pembangunan berkelanjutan, dimana ada argumentasi bahwa suatu perusahaan dalam melaksanakan aktivitasnya harus mendasarkan keputusannya tidak semata berdasarkan faktor keuangan, misalnya keuntungan atau deviden melainkan juga harus berdasarkan konsekuensi sosial dan lingkungan untuk saat ini maupun untuk jangka panjang. ${ }^{17}$

Dunia usaha merupakan bagian dari komunitas masyarakat dan memiliki tanggung jawab sosial yang sama dengan masyarakat. Pada kenyataannya, tidak dapat dipungkiri bahwa peran dunia usaha selama ini hanya sebatas pemberian dukungan dana secara sukarela (voluntary) dan kedermawanan (philanthropy) sehingga kegiatan yang dilaksanakan kurang memberikan manfaat nyata bagi masyarakat. Hal ini memunculkan rasa kekecewaan masyarakat dan pemerintah akan minimnya peran dunia usaha dalam kehidupan sosial dan adanya kecenderungan bahwa pelaksanaan

CSR hanya sekedar untuk di mata masyarakat atau bahkan hanya di mata konsumen mereka. Dari sudut pandang Pemerintah, apabila CSR/TJSL diterapkan secara sukarela maka yang akan terjadi adalah pengrusakan lingkungan dan ketidakpedulian perusahaan terhadap lingkungannya. Contohnya seperti kasus kerusakan lingkungan di lokasi penambangan timah inkonvensional di pantai Pulau Bangka-Belitung dan tidak dapat ditentukan siapakah pihak yang bertanggung jawab atas kerusakan yang terjadi karena kegiatan pembangunan dilakukan oleh penambang rakyat tidak berizin yang mengejar setoran pada PT. Timah, Tbk. Sebagai akibat dari penambangan inkonvensional tersebut

17 Franz Magnis Suseno, Etika Bisnis : dasar Dan Aplikasinya. Jakarta : Gramedia, 2004, hlm 35 terjadi pencemaran air permukaan laut dan perairan umum, lahan menjadi tandus, terjadi abrasi pantai, dan kerusakan laut. ${ }^{18}$ Contoh lain adalah konflik antara PT. Freeport Indonesia dengan rakyat Papua. Penggunaan lahan tanah terdapat perusakan dan penghancuran lingkungan hidup, penghancuran perekonomian, dan pengikaran eksistensi penduduk Amungme merupakan kenyataan pahit yang harus diterima rakyat Papua akibat keberadaan operasi penambangan PT. Freeport Indonesia. Bencana kerusakan lingkungan hidup dan komunitas lain yang ditimbulkan adalah jebolnya Danau Wanagon hingga tiga kali akibat pembuangan limbah yang sangat besar kapasitasnya dan tidak sesuai dengan daya dukung dan daya tampung lingkungan sekitar.

\section{KONSEP CORPORATE SOCIAL RESPONSIBILITY (CSR) BERDASARKAN UNDANG-UNDANG TENTANG PERSEROAN TERBATAS}

Tanggung CSR/TJSL dapat mendorong terwujudnya kesejahteraan rakyat karena adanya alokasi dana dari perusahaan untuk meningkatkan kesejahteraan masyarakat sekitar. Pelaku usaha harus bekerja sama dengan Pemerintah dalam upaya mensejahterakan rakyat. ${ }^{19}$ Sistem

18 Lina Anatan, “Corporate Social Responsibility (CSR) : Tinjauan Teoritis dan Praktik di Indonesia", (Bandung : Fakultas Ekonomi Universitas Kristen Maranatha, 2010), hal. 2.

${ }^{19}$ Kesejahteraan rakyat tersirat sebagai tugas Pemerintah melalui Alinea-IV Pembukaan UUD 1945, yang menyatakan bahwa : "Kemudian dari pada itu untuk membentuk suatu Pemerintah Negara Indonesia yang melindungi segenap bangsa Indonesia dan seluruh tumpah darah Indonesia dan untuk memajukan kesejahteraan umum, mencerdaskan kehidupan bangsa dan ikut melaksanakan ketertiban dunia yang berdasarkan kemerdekaan, perdamaian abadi, dan keadilan sosial, maka disusunlah Kemerdekaan Kebangsaan Indonesia itu dalam suatu Undang-Undang Dasar Negara Indonesia, yang berbentuk dalam suatu susunan Negara Republik Indonesia, yang berkedaulatan rakyat dengan berdasar kepada : Ketuhanan Yang Maha Esa, Kemanusiaan yang adil dan beradab, Persatuan Indonesia, dan Kerakyatan 
Pemerintahan Indonesia menganut sistem demokrasi, yaitu pemerintahan yang berasal dari rakyat, untuk rakyat, dan oleh rakyat. Dengan demikian, pembangunan kesejahteraan rakyat berasal dari rakyat melalui pajak, untuk rakyat melalui pembangunan infrastruktur daerahdaerah, dan oleh rakyat melalui perwakilan rakyat (lembaga legislatif - DPR) yang menyusun program pembangunan bangsa melalui Anggaran Pendapatan dan Belanja Negara (APBN). ${ }^{20}$

Tanggung jawab perusahaan terhadap program CSR/TJSL yang dilaksanakan berdasarkan Pasal 74 Undang-Undang No. 40 Tahun 2007 tentang Perseroan Terbatas adalah bersifat mandatory. Tetapi apabila ukuran kepatutan dan kewajaran dalam pelaksanaan program CSR/TJSL ditetapkan oleh perusahaan sebagai pelaksana program CSR/TJSL, maka pelaksanaan CSR/TJSL tersebut akan lebih bersifat kedermawanan dan kesukarelaan dari pada sebuah kewajiban yang sifatnya mandatory. ${ }^{21}$

Harus dibedakan antara pungutan pajak oleh negara dan dana perusahaan untuk CSR/TJSL. Uang pungutan pajak digunakan untuk pembangunan secara nasional, sedangkan dana TJSL

yang dipimpin oleh hikmat kebijaksanaan dalam permusyawaratan/perwakilan, serta dengan mewujudkan suatu Keadilan sosial bagi seluruh rakyat Indonesia".

${ }^{20}$ Apabila Pemerintah di Amerika Serikat ditanya dari mana dana pembangunan negara didapat maka jawabannya adalah dari pajak. Sedangkan di Indonesia, apabila ditanya pertanyaan yang sama maka jawabnya adalah dari APBN.

Kedua jawaban yang berbeda di atas mencerminkan perbedaan paradigma pengetahuan Pemerintah mengenai asal pembangunan dilakukan. Itulah makna dari demokrasi (berasal dari rakyat, untuk rakyat, dan oleh rakyat). Maka jawaban yang paling benar, bahwa pembangunan berasal dari pajak masyarakat.

${ }^{21}$ Kesimpulan mengenai pandangan pelaku usaha terhadap CSR/TJSL sebagai kewajiban hukum bagi perusahaan. Didapat dari tesis Anggusti Martono sebagai Anggota Kamar Dagang dan Industri (KADIN) Sumatera Utara dengan demikian wawancara dapat diwakilkan dengan karya ilmiah yang dihasilkan. Sumber : Anggusti Martono, Op.cit. dipergunakan bagi masyarakat sekitar perusahaan dan pemulihan lingkungan dimana perusahaan berada, sehingga terhadap kedua hal tersebut tidak dapat digeneralisir. Perusahaan menginginkan bahwa urusan kesejahteraan masyarakat sepenuhnya adalah urusan Pemerintah, sedangkan perusahaan hanya mencari keuntungan untuk membiayai perusahaan dan memberikan keuntungan kepada pemegang sahamnya.

Hal yang menjadi permasalahan lanjutan apabila CSR/TJSL dijadikan sebagai tanggung jawab hukum bagi perusahaan adalah mengenai hak dan kewajiban perusahaan. Kewajiban perusahaan adalah melaksanakan CSR/TJSL sesuai dengan ketentuan yang berlaku baik itu Undang-Undang Sektoral maupun Undang-Undang No. 40 Tahun 2007 tentang Perseroan Terbatas. Selanjutnya, hak perusahaan inilah yang tidak diperhatikan oleh Pemerintah. Infrastruktur tetap saja tidak baik, pungutan liar tetap terjadi, dan birokrasi perizinan selalu mempersulit. Seharusnya infrastruktur dibenahi terlebih dahulu, pungutan liar ditiadakan, dan birokrasi perizinan dibuat satu pintu barulah CSR/TJSL dijadikan sebagai kewajiban hukum. ${ }^{22}$

Di dalam hukum apabila berbicara tanggung jawab tidak terlepas berbicara mengenai kewajiban dan hak. CSR/TJSL menjadi kewajiban bagi perusahaan, namun Pemerintah tidak memberikan hak kepada perusahaan (infrastruktur yang baik, tidak adanya pungutan liar, dan perizinan yang satu pintu). Untuk mengatur permasalahan tersebut, Pemerintah perlu mengupayakan segala tindakan yang berpihak kepada pelaku usaha. Jangan hanya mengutip pajak yang semakin tahun semakin tinggi dari pelaku usaha.

\section{PELAKSANAAN TANGGUNG JAWAB SOSIAL DAN LINGKUNGAN MENURUT}

22 Mahkamah Konstitusi Republik Indonesia, “Putusan Nomor 53/PUU-VI/2008”, hal. 92. 


\section{UNDANG-UNDANG NO. 40 TAHUN 2007 TENTANG PERSEROAN TERBATAS}

Pemberlakuan CSR/TJSL harus berdasarkan kepatutan dan kewajaran, dalam Putusan MK No. 53/PUU-VII/2008 mengutarakan bahwa "...Perusahaan sendirilah yang melaksanakan TJSL sesuai dengan prinsip kepatutan dan kewajaran.". Namun, dalam hal ini standarisasi kepatutan dan kewajaran tidak ditentukan oleh Undang- Undang No. 40 Tahun 2007 tentang Perseroan Terbatas. Ketentuan tersebut akan diatur dalam Peraturan Pemerintah tetapi, Peraturan Pemerintah ini juga tidak dikeluarkan.

Apabila dilihat dari dalil Mahkamah mengenai "kepatutan dan kewajaran" tersebut tersirat makna bahwa kata "kepatutan dan kewajaran" tersebut dijadikan sebagai alasan pembenaran dalam pelaksanaan CSR/TJSL berdasarkan Pasal 74 Undang-Undang No. 40 Tahun 2007 tentang Perseroan Terbatas. Kepatutan dan kewajaran memiliki arti yang berbeda bagi tiap-tiap perusahaan. Oleh karena itu, perlu adanya suatu keseragaman dalam hal kewajaran dan kepatutan tersebut.

"Kepatutan dan kewajaran tersebut bersifat ambigu. Secara umum Pasal 74 meregulasi CSR dalam satu sudut pandang saja, yakni kewajiban perusahaan, tetapi tidak meregulasi peran dan tanggung jawab pihak lain yang juga terkait dengan pencapaian sasaran CSR, seperti pemerintah dan masyarakat". Patut dan wajar ini bisa dijadikan sebagai jalan keluar/alasan bagi perusahaan yang melakukan CSR/TJSL secara tidak serius atau dengan kata lain menganggarkan sedikit dana dari pendapatan/keuntungan yang berlipat. Sudah dapat dipastikan akan terjadi permasalahan di kemudian hari. Masyarakat tentu tidak terima dengan pelaksanaan program CSR/TJSL yang sedikit menganggarkan dana. Contohnya PT. Freeport Indonesia, yang mengambil emas dari tanah Papua setiap hari, tetapi berbeda jauh dengan keadaan dan kondisi masyarakatnya yang hidup di bawah garis kemiskinan.

Maka dari itu, diharapkan agar segera mengeluarkan peraturan pelaksana Pasal 74 Undang-Undang No. 40 Tahun 2007 tentang Perseroan Terbatas. Memberikan fleksibilitas kepada perusahaan untuk menetapkan standar kepatutan dan kewajaran dalam pelaksanaan CSR/TJSL, serta mengatur secara tegas dan berkeadilan hukum mengenai peran dan tanggung jawab tri-partit (pemerintah, perusahaan, dan masyarakat setempat). Peraturan pelaksana tersebut disusun dengan memperhatikan aspek rasa keadilan (fairness), keseimbangan hak dan kewajiban (balance), kepastian tentang status dan definisi (clearity of status and definition), terbuka (tranparance) dan akomodatif terhadap semua kepentingan (accommodative), sehingga diharapkan regulasi CSR/TJSL bermanfaat secara menyeluruh bagi pembangunan ekonomi nasional.

Aspek-aspek pelaksanaan CSR/TJSL tersebut, dengan kata lain dapat disebut sebagai prinsip-prinsip CSR/TJSL. Apabila perusahaan tidak mengikuti prinsipprinsip tanggung jawab sosial, maka perusahaan akan mengalami kesulitan dalam menerapkannya. Melaksanakan prinsip lebih penting daripada mengharapkan pengaturan dan penegakan aturan, karena dengan menerapkan prinsip-prinsip berarti semua pihak akan mengatur diri sendiri (self-regulation). Hal ini menjadi penting dalam keadaan dimana banyak pihak belum menerapkan tata kelola yang baik atau goodgovernance, sehingga dapat diharapkan adanya keadaan "tata kelola yang cukup baik" (good corporate governance). Berkaitan dengan CSR/TJSL, "tata kelola cukup baik" mengandung makna bahwa semua pihak sedapat mungkin mengatur diri sendiri dalam menerapkan prinsip-prinsip tanggung jawab sosial.

Semua prinsip ternyata saling terkait, misalnya transparansi. Bermula dari 
transparansi, akuntabilitas akan terdorong karena pihak lain akan lebih banyak tahu tentang prinsip yang digunakan maupun program yang akan dilaksanakan, sehingga memungkinkan untuk bertanya atau melaporkan apabila tidak sesuai. Dalam keadaan masih sering terjadi pelanggaran terhadap aturan yang berlaku atau berusaha untuk mencari kemudahan, penegakan hukum adalah hal yang penting untuk mendorong para pihak melakukan CSR/TJSL minimalnya (sesuai aturan yang ditetapkan). Selain itu penghargaan memberi apresiasi kepada pihak yang sudah berusaha untuk tidak hanya melakukan kewajiban tetapi juga berinisiatif untuk mengambil peran lebih.

\section{KESIMPULAN}

Berdasarkan hasil penelitian dapat disimpulkan sebagai berikut :

1. Tanggung jawab perusahaan terhadap program CSR/TJSL yang dilaksanakan berdasarkan Pasal 74 Undang-Undang No. 40 Tahun 2007 tentang Perseroan Terbatas adalah bersifat mandatory. Tetapi apabila ukuran kepatutan dan kewajaran dalam pelaksanaan program CSR/TJSL ditetapkan oleh perusahaan sebagai pelaksana program CSR/TJSL, maka pelaksanaan CSR/TJSL tersebut akan lebih bersifat kedermawanan dan kesukarelaan dari pada sebuah kewajiban yang sifatnya mandatory, dengan demikian Tanggung CSR/TJSL dapat mendorong terwujudnya kesejahteraan rakyat karena adanya alokasi dana dari perusahaan untuk meningkatkan kesejahteraan masyarakat sekitar. Pelaku usaha harus bekerja sama dengan Pemerintah dalam upaya mensejahterakan rakyat

2. Pelaksanaan Tanggung Jawab Sosial dan Lingkungan menurut UndangUndang No. 40 Tahun 2007 tentang Perseroan Terbatas Apabila dilihat dari dalil Mahkamah Konstitusi mengenai "kepatutan dan kewajaran" tersebut tersirat makna bahwa kata "kepatutan dan kewajaran" tersebut dijadikan sebagai alasan pembenaran dalam pelaksanaan CSR/TJSL berdasarkan Pasal 74 Undang-Undang No. 40 Tahun 2007 tentang Perseroan Terbatas. Kepatutan dan kewajaran memiliki arti yang berbeda bagi tiap-tiap perusahaan. Oleh karena itu, perlu adanya suatu keseragaman dalam hal kewajaran dan kepatutan tersebut. "Kepatutan dan kewajaran tersebut bersifat ambigu. Secara umum Pasal 74 meregulasi CSR dalam satu sudut pandang saja, yakni kewajiban perusahaan, tetapi tidak meregulasi peran dan tanggung jawab pihak lain yang juga terkait dengan pencapaian sasaran CSR, seperti pemerintah dan masyarakat".

\section{SARAN}

Berdasarkan kesimpulan diatas, maka dapat disarankan sebagai berikut :

1. Mengenai tidak adanya Peraturan Pemerintah yang mengatur mengenai sanksi dalam penerapan CSR/TJSL berdasarkan Pasal 74, maka sebaiknya Pemerintah mengeluarkan ketentuan pelaksana CSR/TJSL berdasarkan Pasal 74 ayat (4) Undang-Undang No. 40 Tahun 2007 tentang Perseroan Terbatas. Hal ini untuk menjawab seluruh pertentangan di dunia akademisi maupun dunia usaha mengenai pro dan kontra pelaksanaan CSR/TJSL.

2. Mengenai konsep CSR/TJSL yang dilihat dari aspek efisien dan keadilan, seharusnya Pemerintah membenahi terlebih dahulu iklim investasi di Indonesia barulah menetapkan CSR/TJSL sebagai kewajiban hukum. Iklim investasi tersebut, antara lain mengenai perizinan, pungutan liar, dan infrastruktur. Setelah seluruh hal tersebut dibenahi barulah penerapan CSR/TJSL sebagai kewajiban hukum mencerminkan keadilan. Karena kewajiban tidak terlepas dari hak, barulah hukum itu adil. 


\section{UCAPAN TERIMA KASIH}

\section{DAFTAR PUSTAKA}

Bartens, Kees., Pengantar Etika Bisnis, Cetakan Kesepuluh, Yogyakarta : Kanisius, 2000.

Belal, Ataur Rahman., Corporate Social Responsibility Reporting in Developing Country : The Case of Bangladesh, Burlington : Ashgate Publishing Company, 2008.

Erawaty, AF. Elly., "Persoalan Hukum Seputar Tanggung Jawab Sosial Perseroan Dalam Perundang-Undangan Ekonomi Indonesia", Jakarta : Kementerian Hukum \& HAM RI, Direktorat Jenderal Peraturan Perundangan-Undangan, Media Publikasi Peraturan Perundang-Undangan dan Informasi Hukum, 28 Oktober 2010.

Hariyanto, "Tanggung Jawab Sosial Perusahaan Terhadap Stakeholder", Medan : Tesis, Universitas Sumatera Utara, 2010.

Kusumaatmadja, Mochtar., Hukum, Masyarakat dan Pembinaan Hukum Nasional, Bandung : Binacipta, Tanpa Tahun.

Kotler, Philip., dan Nancy Lee, Corporate Social Responsibility : Doing the Most Good for Your Company and Your Cause, Canada : John Wiley \& Sons, Inc., 2005.

Mares, Radu., The Dynamics of Corporate Social Responsibility, Leiden : Koninklijke Brill NV, 2008.

Marzuki, Peter Mahmud., Penelitian Hukum, Edisi Pertama, Cetakan Keenam, Jakarta : Kencana, 2010.

Simatupang, Dian Puji N., "Penyusunan Proposal Penelitian", Bahan Perkuliahan Metode Penelitian dan Penulisan Hukum, Depok : Fakultas Hukum Universitas Indonesia, 27 Februari 2008.

Simorangkir, OP., Etika : Bisnis, Jabatan, dan Perbankan, Jakarta : Rineka Cipta, 2003.

Teguh, "Tanggung Jawab Sosial Harus Dilakukan", makalah disampaikan pada "Corporate Social Responsibility : Integrating Social Aspec into The Business”, Yogjakarta, 2006.

Waluyo, Bambang., Penelitian Hukum dalam Praktek, Jakarta : Sinar Grafika, 1996. 